\section{朝日山系「大鳥池」の 1973 年盛夏における状況}

加藏 武雄・高獢太治三

大鳥池に関しては，1955 年に加藤（1957）によりは じめて湖沼学的な調查が行なわれたが，ひきつづき 1959 年任上野 (1959) らに上って総合的炕調査され, 宋た高 橋（1961）によりプランクトンの観測がなされた。しか し，その後十数年にわたって，その調查は絶えている が, この湖沼は朝日の山岳地带に位置し, 踏查には幾多

\section{第1表 大鳥池周辺の陸水の性質（1973 年 8 月 8} 日)

\begin{tabular}{|c|c|c|c|c|c|}
\hline & 束沢 & 中沢 & 西沢 & 大鳥 & \\
\hline Tw $\quad\left({ }^{\circ} \mathrm{C}\right)$ & 16.8 & 17.0 & 11.0 & 18.1 & 19. \\
\hline $\mathrm{pH}$ & & & .9 & 6.5 & \\
\hline $\mathrm{T}-\operatorname{Re}(\mathrm{mg} / \mathrm{l})$ & 18 & 20 & 18 & 18 & 13 \\
\hline $\mathrm{O} \quad(\mathrm{mg} / \mathrm{l})$ & 11.82 & 11.95 & 13.36 & 11.33 & 10.81 \\
\hline $4.3 \mathrm{Bx}(\mathrm{me} / \mathrm{l})$ & 0.15 & .23 & 0.22 & .11 & 0.13 \\
\hline l) & 0.43 & 0.88 & 0.38 & .77 & 1.0 \\
\hline $\mathrm{Na}^{+}(\mathrm{mg} / \mathrm{l})$ & 1.9 & 2.5 & 1.8 & 1.9 & 1.6 \\
\hline $\mathrm{K}^{+} \quad(" \prime)$ & 0.20 & 0.25 & 0.20 & 0.20 & 0.20 \\
\hline $\left.\mathrm{Ca}^{2+}(")\right)$ & 1.0 & 1.8 & 2.2 & .2 & 1.1 \\
\hline $\mathrm{Mg}^{2+}(" \prime)$ & 0.58 & 0.77 & 0.62 & 0.38 & 0.45 \\
\hline $\mathrm{Cr}(\|)$ & 1.2 & 2.1 & 1.3 & 1.2 & 1.2 \\
\hline $\mathrm{SO}_{4}^{2-}(" \prime)$ & 1.2 & 1.2 & 3.3 & 2.5 & 1.7 \\
\hline$(1,1)$ & 7.0 & 9.0 & 5.9 & 5.7 & 5.6 \\
\hline $\mathrm{NO}_{2}^{-}-\mathrm{N}(\mu \mathrm{g} / l)$ & 8.9 & 9.5 & 7.4 & 10.5 & 7.8 \\
\hline$\overline{3}-\mathrm{N}(\mathrm{mg} / \mathrm{l})$ & 0.14 & 0.11 & 0.11 & 0.084 & 0.088 \\
\hline 流量 $\left(\mathrm{m}^{3} / \mathrm{se}\right.$ & 0.44 & 0.067 & 0.058 & - & 1.57 \\
\hline
\end{tabular}

（注） $\mathrm{T}_{a}=21.2^{\circ} \mathrm{C}$ (14時30分)

第 2 表 大鳥池表面水の一次生産（1973 年 8 月 8 日 5 時〜 9 日 5 時)

\begin{tabular}{c|cc}
\hline \hline 純生産 量 & 0.14 & $\mathrm{mg} \mathrm{O} / l \cdot$ day \\
分 解 量 & 0.01 & $"$ \\
総生産量 & 0.15 & $" \prime$ \\
\hline
\end{tabular}

の困難を伴らからである。さいわいに 1973 年 8 月にこ の湖水之その流出入河川について二, 三の陸水学的調查 を行なうことができたので，短報として記録にとどめた い。

結果は第 1,2 表に見られるように，大鳥池は現在でも 貧栄養湖の性格总維持し, 以前より富栄養化が進んでい ない。また第1表より,この湖㳅の流入・流出河川の日 流量を計算すると，それぞれ $49,000 \mathrm{~m}^{3}, 136,000 \mathrm{~m}^{3}$ と なり，その差 $87,000 \mathrm{~m}^{3}$ に湖面からの蒸発量 $(3.42 \times$ $10^{5} \mathrm{~m}^{2} \times 0.01 \mathrm{~m} /$ day $=3,420 \mathrm{~m}^{3} /$ day） を加光た 90,000 $\mathrm{m}^{3}$ が，大鳥池を涵養する地下水の日量であることを知 った。

(1974. 1. 11 受理)

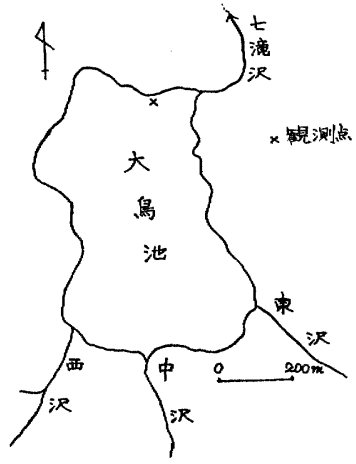

大鳥池略図

文

献

加藤武雄（1957）：大鳥池に関する二，三の湖沼学的知 見 地理評 $30 \quad 304 \sim 307$

高橋永治 (1961): Observations on the Plankton in the Littoral Region of Lake Otori-ike 山形大 学紀要 (農学) 3 3 $33 \sim 51$

上野益三 (1959)：山形県大鳥池 陸水雑 20 121 144

\title{
Limnological Survey of Lake Ôtori-ike in August, 1973
}

\section{Takeo KATô and Tajimi TAKAHASHI}

Eigthteen years have already passed since our first exploration of Lake Ōtori-ike. The difficult accessibility of the lake from the nearest village has made it ignored by the limnologists for these ten years. In August, 1973 the survey was carried out by the authors with the following results: 1955.

1) The lake has maintained the low productivity, i.e. it has been oligotrophic since

2) The ground water supply into the lake is $90,000 \mathrm{~m}^{3} /$ day while the inflow of the surface water measures only $49,000 \mathrm{~m}^{3} /$ day. 